\title{
25 Research Square

\section{Ant diversity and abundance in pasture system and two agricultural land uses in the Rashad district, Southern Sudan}

Khalid A. E. Eisawi

Northwest A\&F University

Indra Prasad Subedi

Tribhuvan University

Omer M. Abdalla

University of Zalingei

Hong He ( $\nabla$ nfash555@gmail.com )

Northwest A\&F University

\section{Research Article}

Keywords: Biodversity, Distribution, Conservation, Dominance, Rashad, Southern Kordofan

Posted Date: November 8th, 2021

DOI: https://doi.org/10.21203/rs.3.rs-1060575/v1

License: (c) (i) This work is licensed under a Creative Commons Attribution 4.0 International License.

Read Full License 


\section{Abstract}

The most common ecological consequence of biodiversity loss is a reduction in ecosystem functions. These responses, however, vary depending on the type of land-use change and the ecological setting. This study investigated the impact of land-use type and ecosystem functions on the ant assemblage of Rashad district, Sudan. Therefore, the purposes of this study are to evaluate the composition and structure of the ant assembly in the station, as well as to determine the trophic guilds and functional groups and their spatial variation in three different land uses. Furthermore, based on the type of land use to determine how the conversion of native vegetation affects the richness and composition of ant species. In each location, we sampled three 20-meter-long transects (Sample plot). Each sample plot consisted of a grid of 12 pitfall traps arranged in three rows of four traps each, with a $2 \mathrm{~m}$ spacing between them, replicated six times in a single year. We collected 38 ant species from four subfamilies and 17 genera. Parasyscia lamborni was the most abundant species followed by Bothroponera crassa. Ant diversity was higher in Soy monoculture and Organic farming than in the Pasture. The frequency distributions of ant Functional groups in Soy monoculture and Organic farming were significantly different from the frequency distributions in the pasture. The omnivorous and predator's trophic guilds were the best represented and regarding functional groups. We found a high proportion of tropical climate specialists and Myrmicinae generalists. These findings suggest that Pasture Activation reduces ant diversity. It can also help to increase the population of species with a diverse diet that predominate in areas where stress and disturbance prevent other ants from reproducing.

\section{Introduction}

Ants are an ideal group to study landscape ecology because they are important ecological indicators, with a wide taxonomic diversity, of trophic and functional guilds, which operate in almost all strata of agroecosystems (Arenas et al., 2019); additionally, due to its abundance, the ecological fidelity of some groups, the presence of characteristic species of disturbed habitats, and species of economic importance (Suguituru et al., 2011).

Insects play an important role in ecosystems, influencing the composition and size of populations of plants, herbivores, predators and detritivores (Folgarait, 1998; Bruhl et al., 2003). Fire has an impact on the insect community, vegetation heterogeneity, seasonality, fragmentation (Hansen et al., 2012).

Land conversion to agrosystems has been deemed detrimental to biodiversity conservation (Lappola et al., 2006). Agricultural systems result from the conversion of complex natural ecosystems to simplified ecosystems through the intensive use of machinery, chemical and biological inputs, as well as improved and modified crops (Viglizzo et al., 2001). These agrosystems are a major cause of biodiversity loss because of fragmentation and destruction of native vegetation (Amara et al., 2020). However, the effects of land use change on native fauna depend on the size of divergence of pre- and post-land use conversion ecological conditions (Sid-Ali et al. 2021). There are thus agricultural systems that have a high impact on native fauna and flora, and other types of low impact agricultural systems, which can 
play a key role in species conservation (Vasconcelos et al., 2008; Klimes et al., 2012), as the landscape Low-affected agriculture can harbor much of the world's biodiversity, and the relative contribution of each type of agrosystem to conservation is understood (Majer et al., 2007). The impact of land-use changes on ant diversity in the Rashad district of Southern Kordofan, Sudan Basin, is poorly understood. It is worthnoting that very little research on ant variety has been undertaken in Central Africa, particularly in Cameroon. Published research has primarily focused on ant diversity in forests, with little attention paid to other prominent vegetation types, such as grasslands and mixed-crop fields (Watt et al., 2002; Fotso Kuate et al., 2015).

The aim of this study was to evaluate the composition and structure of ant assembly in the Station and to determine the trophic guilds,functional groups and their spatial variation in three different land uses. Furthermore, to determine how the conversion native vegetation affects the richness and composition of ant species based on the type of land use.

\section{Materials And Methods}

\section{Location and description of the study area}

This study was conducted in the Rashad district from February to June 2019 and February to May 2021, covering an area of $7872 \mathrm{~km}^{2}$ in the center of Kordofan between latitudes $10^{\circ}, 13^{\circ} \mathrm{N}$ and longitudes $29^{\circ}$, $33^{\circ} \mathrm{E}$, as shown in Fig. 1 ( Abtew et al., 2012), in areas such as pasture, soy monoculture, and organic agriculture, as well as areas of native vegetation. Fourty four sites were sampled: 15 soy monoculture, 15 pastures, 15 organic agriculture areas. The annual rainfall in the study area ranges between 500 and 800 mm (Fig. 2). The majority of the basement complex in the area is overlaid with Nubian sandstone. According to Eisawi et al. (2021), vegetation cover in the Rashad area comprises of legumes dominated by the Acacia genus annual grasses, and shrubs. The vegetation, on the other hand, varies according to rainfall patterns and soil structure.

\section{Sample design}

We sampled three 20-meter-long transects in each location (Sample plot) (Fig. 3a). Each sample plot was made up of a grid of 12 pitfall traps, which were arranged in three rows of four traps each, with a two meter spacing between them (Fig. 3b). The pitfall traps are $200 \mathrm{ml}$ plastic cups that have been filled up to $1 / 3$ with water and detergent, and have been active for 24 hours in the field. There were 12 pitfalls per plot, 36 per location, and 2,484 in 45 locations (Fig. 3c).

The contents of each trap were sieved (in a fine mesh to reduce the loss of tiny invertebrates) and preserved in a 75\% alcohol container before sorting. We combined all 12 pitfalls from each sample plot into a single composite sample to shorten the screening time. All ants were manually sorted and preserved in $70 \%$ alcohol. Few ants were Point-mounted for taxonomic and morphometric studies (Lattke et al., 2018). Specimens were identified using a single key to identify subfamilies, a series of keys to 
identify genera and a series of keys to identify species (Bingham 1903; Holldobler and Wilson, 1990; Mathew and Tiwari 2000), and comparison with voucher specimens, comparison with type images available at AntWeb, AntWiki.

\section{Data analysis}

The Mao Tau method was used to create species accumulation curves, which were then used to analyze the total ant species richness in different land-use systems. When the 95 percent confidence intervals did not overlap, there was a statistically significant difference in the total ant species richness between landuse (de Castro Solar et al., 2016).

The number of ant subfamilies, genera, and morphospecies, as well as the presence or absence of morphospecies, were determined in each sample. Regardless of the number of specimens found in each sample, each record corresponds to the appearance of a morphospecies in it. With the number of records, the Shannon-Wienner, Dominance, Pielou equity indices and the Chao2 estimator were calculated for each land use, using the PAST statistical program (Hammer et al., 2001). The values of the ShannonWienner diversity and Simpson dominance indices between land uses were compared using Hutcheson's T tests (Klukowski, 2011). The similarity between morphospecies present in the different land uses was estimated using the Jaccard index. The rarity of morphospecies found in the different land uses was determined as the species that occurred exclusively in a single sampling site. To determine differences in the number of records between subfamilies, trophic guilds, and functional groups by land use, the percentage values of records of each of them were compared among the different samples taken, by means of one-way analysis of variance (ANOVA), validating that the data complied with the assumptions of normality (Shapiro-Wilk test) and homoscedasticity (Levene's test) and comparisons (post hoc), which were evaluated, using the Tukey test and when they did not meet the assumptions, the comparisons were used Mann-Whitney paired, using the PAST statistical program (Hammer et al., 2001).

\section{Results}

\section{Composition of the ant community and diversity indices}

A total of 5,239 ant, from 38 species in 4 subfamilies and 17 genera were recorded in the three vegetation types (Table 1). The subfamily Ponerinae was the most diversified with 8 genera and 16 species, followed by Myrmicinae ( 2 genera and 10 species), Formicinae (4 genera and 8 species) and Dorylinae (3 genera and 5 species) (Table 1). The most speciose genus was Pheidole (8 species), followed by Bothroponera, Hypoponera, Leptogenys and Camponotus (3 species each) (Fig. 4). 
Table 1

Ant species collected at Organic farming, Soy monoculture and in an active pasture in the Rashad district, Southern Kordofan, Sudan.

\section{Land- uses}

\section{Subfamiliy Species}

1. Aenictus pharaoh Santschi, 1924

Dorylinae

2. Dorylus aethiopicus Emery, 1895

3. Dorylus sudanicus Santschi, 1917

4. Parasyscia lamborni Crawley, 1923

5. Parasyscia sudanensis Weber, 1942

6. Anochetus sedilloti Emery, 1884

7. Anochetus traegaordhi Mayr, 1904

8. Bothroponera crassa Emery, 1877

9. Bothroponera pachyderma Emery, 1901

\section{Organic \\ farming}

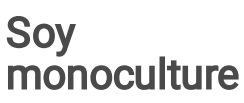

0

4

0

1

3

2

0

0

0

0

2

0 1862

10. Bothroponera soror Emery, 1899

11. Brachyponera sennaarensis Mayr,

Ponerinae 12. Euponera brunoi Forel, 1913

13. Fisheropone ambigua Weber, 1942

14. Hypoponera dulcis Forel, 1907

15. Hypoponera jeanneli Santschi, 1935

16. Hypoponera punctatissima Roger, 3 1859

17. Leptogenys crustose Santschi, 1914

18. Leptogenys maxillosa Smith, F., 1858

19. Leptogenys pavesii Emery, 1892

0

20. Leptogenys stuhlmanni Mayr, 1893

21. Megaponera analis Latreille, 1802

3

22. Calyptomyrmex brevis Weber, 1943

14

7

2

1

1

0

3

1

1

3

5

1

2

5

0

4

1

Pasture 1

0

0

24

1

1

0

0

0

0

9

0

0

1

3

0 0 0 0 0 


\begin{tabular}{|c|c|c|c|c|}
\hline & & \multicolumn{3}{|c|}{ Land- uses } \\
\hline & $\begin{array}{l}\text { 23. Calyptomyrmex piripilis Santschi, } \\
1923\end{array}$ & 0 & 6 & 1 \\
\hline & 24. Pheidole aeberlii Forel, 1894 & 0 & 0 & 0 \\
\hline & 25. Pheidole decarinata Santschi, 1929 & 0 & 9 & 0 \\
\hline & 26. Pheidole jordanica Saulcy, 1874 & 2 & 3 & 0 \\
\hline \multirow[t]{8}{*}{ Myrmicinae } & $\begin{array}{l}\text { 27. Pheidole megacephala Fabricius, } \\
1793\end{array}$ & 0 & 1 & 0 \\
\hline & 28. Pheidole sculpturata Mayr, 1866 & 1 & 1 & 0 \\
\hline & 29. Pheidole sinaitica Mayr, 1862 & 1 & 8 & 1 \\
\hline & 30. Pheidole speculifera Emery, 1877 & 1 & 0 & 0 \\
\hline & 31. Pheidole termitophila Forel, 1904 & 1 & 1 & 0 \\
\hline & $\begin{array}{l}\text { 32. Pristomyrmex africanus Karavaiev, } \\
1931\end{array}$ & 0 & 0 & 0 \\
\hline & $\begin{array}{l}\text { 33. Camponotus acvapimensis Mayr, } \\
1862\end{array}$ & 12 & 12 & 0 \\
\hline & $\begin{array}{l}\text { 34. Camponotus aegyptiacus Emery, } \\
1915\end{array}$ & 0 & 2 & 1 \\
\hline \multirow[t]{5}{*}{ Formicinae } & 35. Camponotus bayeri Forel, 1913 & 0 & 7 & 7 \\
\hline & 36. Lepisiota frauenfeldi Mayr, 1855 & 3 & 3 & 0 \\
\hline & 37. Lepisiota validiuscula Emery, 1897 & 0 & 1 & 4 \\
\hline & $\begin{array}{l}\text { 38. Nylanderia jaegerskioeldi Mayr, } \\
\text { 1904 }\end{array}$ & 6 & 2 & 5 \\
\hline & Total & 107 & 97 & 77 \\
\hline
\end{tabular}

The most abundant ant species was Parasyscia lamborni in pasture, followed by Bothroponera crassa in Organic farming and Fisheropone ambigua in pasture, while in soy monoculture Camponotus acvapimensis was recorded with lowest abundance (Fig. 5).

The results of the Shannon diversity $\left(\mathrm{H}^{\prime}\right)$, Simpson index and Equity of Pielou index indices are presented in Table 2. Shannon diversity $\left(\mathrm{H}^{\prime}\right)$ recorded a higher value in Soy monoculture (3.08) than in Organic farming (2.78). For the Simpson index, a lower value was found in Pasture (0.82), with significant differences $(p<0.05)$, with respect to the other land uses. Finally, the Equity of Pielou index ranged between 0.92 in Soy monoculture, followed by 0.86 in Organic farming and 0.77 in pasture (Table 2). The richest habitat was the Soy monoculture 29 species, followed by the Organic farming 25 species and the 
Pasture 15 species. However, there was no significant difference between among habitats, as shown by the non-overlapping 95\% confidence intervals of the three species accumulation curves (Fig. 6).

Table 2

Indices of diversity of ants present in the different land use in the Rashad district, Southern Kordofan, Sudan.

\begin{tabular}{|llll|}
\hline & Organic farming & Soy monoculture & Pasture \\
\hline Number of records (N) & 25 & 29 & 15 \\
\hline Number of individuals (N) & 107 & 97 & 77 \\
\hline Simpson index (1-D) & 0.92 & 0.94 & 0.82 \\
\hline Shannon diversity (H ') & 2.78 & 3.08 & 2.08 \\
\hline Equity of Pielou & 0.86 & 0.92 & 0.77 \\
\hline
\end{tabular}

\section{Functional group diversity}

Litter omnivores and scavengers were the most diverse functional group with 13 species, followed by soil or litter dominant true omnivorous with 10 species, and fungus-growers with8 species. The number of species in each functional group was not significantly different between the vegetation types (Fig. 7). The frequency of ant species richness per guild in the pasture was significantly different from that observed in the Soy monoculture $(\chi 2=25.406 ; p<0.01)$ and Organic farming $(\chi 2=28.76 ; p<0.01)$. In contrast, the frequency of ant species richness in each functional group did not differ significantly between Soy monoculture and Organic farming $(\chi 2=6.633 ; p=0.36)$.

\section{Discussion}

In this study, we discovered 38 species in four subfamilies and 17 genera across three sites. Our findings revealed that the species richness was significantly higher in Soy monoculture and Organic farming than in Pasture. This difference could be attributed to differences in ecological conditions between the three studied areas. The close relationship between ants and the type of habitats has also been reported by Dunn et al. (2000).

The ant communities in the Soy monoculture and Organic farming were different from the communities present in the Pasture; and they may have contained species that were not detected in the sampling. These notable differences might be due to the fact that ant communities are highly influenced by habitat type (Costa-Milanez et al., 2014), and vegetation structure (Luke et al., 2014; Sanabria et al., 2014). Hoffmann et al. (2000) considered low temperature, lack of nest sites, poor food supply, and high structural complexity of foraging surfaces to be the main stressors limiting ant populations. In this study, it is possible that Soy monoculture and Organic farming may provide conditions that favor greater ant abundance, such as nest sites and food supply. The most abundant species at three sites were 
Parasyscia lamborni, Bothroponera crassa and Camponotus acvapimensis. Similar findings have been reported by Fotso Kuate et al. (2015) in different vegetation types of Southern Cameroon, and Hlongwane et al. (2019) in the Sandstone Sourveld in KwaZulu-Natal, South Africa. Our findings are consistent with those reported by Maurice Kouakou et al. (2018) in Côte d'Ivoire (West Africa), who identified the species Bothroponera crassa as one of the most abundant among the Ponerinae and corroborate with those reported by Netshilaphala et al. (2005) in the Namaqualand coast region, South Africa.

The Shannon-Weaver and equitability indices were both high in three sites, as shown in Table 3. However, the most disturbed Soy monoculture had higher Equity Pielou, and Simpson index values. In contrast, the most stable (Soy monoculture) had a higher Shannon diversity $\left(\mathrm{H}^{\prime}\right)$ value. In addition, this site showed close values of Equity Pielou, and Simpson index, indicating that many species have roughly the same abundance. On the contrary, the higher diversity in species of Soy monoculture is characterized by a wide range of abundances among species.

Our findings stem from a sampling procedure associating manual capture and pitfall trap methods. Other researchers used this combined technique to assess ant biodiversity in Sandstone Sourveld in KwaZuluNatal, South Africa. Their results showed lower Shannon diversity H'values: Hlongwane et al. (2019) in the Sandstone Sourveld in KwaZulu-Natal, South Africa noted values ranging from 2.47-3.05 bits. Mauda et al. (2018) reported an Shannon diversity $\left(\mathrm{H}^{\prime}\right)$ value of 1.10 bits at the edges of African savannas. This difference could be due to the fact that our study areas are in different climatic zones: our sites are in a humid area. The difference in functional groups identified across habitats suggests that predator and fungal grower ants are being replaced by soil omnivore ants, as evidenced by the turnover of predator and fungi grower ants. The functional grouping cycle corresponded to the degree of human change and the reduced structural complexity of the habitats, and it was compatible with these factors. Examining the makeup and organization of functional groups in each analyzed environment revealed that the observed species turnover was primarily caused by replacing habitat specialists with generalists. Other studies in different land-use have demonstrated similar replacement of functional categories among habitats (Arnan et al., 2014; Hlongwane et al., 2019), which is consistent with the findings of this study. As a result of these findings, it is now clear that each habitat has a distinct ant assemblage with its unique set of resource requirements and optimal environmental conditions. The reduction in habitat complexity caused by human activities has a significant impact on the number of resources as well as the microclimatic and abiotic conditions that ants experience (Jenkins et al., 2013). Because of human perturbations, the myrmecofauna of Soy monoculture is being replaced by groups of soil or litter dominant true omnivorous ants, which are replacing ant assemblages with very specific ecological requirements in Soy monoculture.

\section{Conclusions}

The current study demonstrated that providing subsidies for ants as environmental indicators might utilize ant communities to analyze the consequences of land-use changes on the environment.

Additionally, it emphasizes the importance of natural forest conservation for the protection of biodiversity in southern Sudan. If the soil is sufficiently fertile, even Soy monoculture in an intermediate ecological 
succession stage can support a diverse fauna that differs from nearby anthropized areas. According to our findings, areas of soy monoculture and organic farming with pasture activity that allow for the development of a healthy understory with native species can support a significant amount of diversity in the ant population.

\section{Declarations}

\section{Acknowledgments}

The authors wish to thank the University of East Kordofan, Northwest A\&F University, for providing funds and facilities. We are grateful to Dr. Francisco Hita Garcia for the identification of the ant species studied in this paper.

\section{Compliance with Ethical Standards}

Conflict of Interest: The authors declare that they have no conflict of interest.

\section{References}

Abtew, A. A., Pretzsch, J., Mohmoud, T. E. S., \& Adam, Y. O. (2012). Commodity chain of frankincense from the dry woodlands of Nuba Mountains, South Kordofan State, Sudan. Small-scale Forestry, 11(3), 365388. doi.org/10.1007/s11842-011-9189-4

Amara, Y., Tliba, H., Bounaceur, F., \& Daoudi-Hacini, S. (2020). Diversity, richness and composition of ant communities (Hymenoptera: Formicidae) in the pre-Saharan steppe of Algeria. Sociobiology, 67(1), 48-58. doi.org/10.13102/sociobiology.v67i1.2897

Arenas-Clavijo, A., \& Armbrecht, I. (2019). Soil ants (Hymenoptera: Formicidae) and ground beetles (Coleoptera: Carabidae) in a coffee agroforestry landscape during a severe-drought period. Agroforestry Systems, 93(5), 1781-1792. doi.org/10.1007/s10457-018-0283-x

Arnan, X., Cerdá, X., \& Retana, J. (2014). Ant functional responses along environmental gradients. Journal of Animal Ecology, 83(6), 1398-1408. doi.org/10.1111/1365-2656.12227

Bingham, C. T. (1903). Hymenoptera: Ants and cuckoo-wasps (Vol. 2). Taylor \& Francis.

Bolton, B. (1994). Identification guide to the ant genera of the world. Harvard University Press.

Brühl, C. A., Eltz, T., \& Linsenmair, K. E. (2003). Size does matter-effects of tropical rainforest fragmentation on the leaf litter ant community in Sabah, Malaysia. Biodiversity \& Conservation, 12(7), 1371-1389. doi.org/10.1023/A:1023621609102

de Castro Solar, R. R., Barlow, J., Andersen, A. N., Schoereder, J. H., Berenguer, E., Ferreira, J. N., \& Gardner, T. A. (2016). Biodiversity consequences of land-use change and forest disturbance in the Amazon: A 
multi-scale assessment using ant communities. Biological Conservation, 197, 98-107. doi.org/10.1016/j.biocon.2016.03.005

Dunn, R. R., Agosti, D., Andersen, A. N., Arnan, X., Bruhl, C. A., Cerdá, X., ... \& Sanders, N. J. (2009). Climatic drivers of hemispheric asymmetry in global patterns of ant species richness. Ecology letters, 12(4), 324333. doi.org/10.1111/j.1461-0248.2009.01291.x

Eisawi, K. A., He, H., Shaheen, T., \& Yasin, E. H. (2021). Assessment of Tree Diversity and Abundance in Rashad Natural Reserved Forest, South Kordofan, Sudan. Open Journal of Forestry, 11(01), 37. doi: 10.4236/ojf.2021.111003

Folgarait, P. J. (1998). Ant biodiversity and its relationship to ecosystem functioning: a review. Biodiversity \& Conservation, 7(9), 1221-1244. doi.org/10.1023/A:1008891901953

Fotso Kuate, A., Hanna, R., Tindo, M., Nanga, S., \& Nagel, P. (2015). Ant diversity in dominant vegetation types of southern Cameroon. Biotropica, 47(1), 94-100. doi.org/10.1111/btp.12182

Hammer, Ø., Harper, D. A., \& Ryan, P. D. (2001). PAST: Paleontological statistics software package for education and data analysis. Palaeontologia electronica, 4(1), 9.

Hansen, A. J., DeFries, R. S., \& Turner, W. (2012). Land use change and biodiversity. In Land change science (pp. 277-299). Springer, Dordrecht. doi.org/10.1007/978-1-4020-2562-4_16

Hlongwane, Z. T., Mwabvu, T., Munyai, T. C., \& Tsvuura, Z. (2019). Epigaeic ant diversity and distribution in the Sandstone Sourveld in KwaZulu-Natal, South Africa. African journal of ecology, 57(3), 382-393. doi.org/10.1111/aje.12615

Hoffmann, B. D., Griffiths, A. D., \& Andersen, A. N. (2000). Responses of ant communities to dry sulfur deposition from mining emissions in semi-arid tropical Australia, with implications for the use of functional groups. Austral Ecology, 25(6), 653-663. doi.org/10.1111/j.1442-9993.2000.tb00071.x

Hölldobler, B., \& Wilson, E. O. (1990). Host tree selection by the Neotropical ant Paraponera clavata (Hymenoptera: Formicidae). Biotropica, 22(2), 213-214.

Jenkins, C. N., Pimm, S. L., \& Joppa, L. N. (2013). Global patterns of terrestrial vertebrate diversity and conservation. Proceedings of the National Academy of Sciences, 110(28), E2602-E2610.

doi.org/10.1073/pnas. 1302251110

Klimes, P., Idigel, C., Rimandai, M., Fayle, T. M., Janda, M., Weiblen, G. D., \& Novotny, V. (2012). Why are there more arboreal ant species in primary than in secondary tropical forests?. Journal of Animal Ecology, 81(5), 1103-1112. doi.org/10.1111/j.1365-2656.2012.02002.x

Klukowski, K. A. (2011). Making executive privilege work: A multi-factor test in an age of czars and congressional oversight. Clev. St. L. Rev., 59, 31. 
Lapolla, J. S., \& Sosa-Calvo, J. (2006). Review of the ant genus Rogeria (Hymenoptera: Formicidae) in Guyana. Zootaxa, 1330(1), 59-68.

Lattke, J. E., Da Silva, T. S., \& Delsinne, T. (2018). Taxonomy and natural history of Strumigenys thaxteri Wheeler and Strumigenys reticeps (Kempf)(Hymenoptera: Formicidae). Zootaxa, 4438(1), 137. doi.org/10.11646/zootaxa.4438.1.6

Luke, S. H., Fayle, T. M., Eggleton, P., Turner, E. C., \& Davies, R. G. (2014). Functional structure of ant and termite assemblages in old growth forest, logged forest and oil palm plantation in Malaysian Borneo. Biodiversity and Conservation, 23(11), 2817-2832. doi.org/10.1007/s10531-014-0750-2

Majer, J., Dunn, R., Gove, A., Barraclough, T., \& Givnish, T. (2007). Convergent evolution of an ant-plant mutualism across plant families, continents and time.

Mathew, R. O. S. A. M. M. A., \& Tiwari, R. N. (2000). Insecta: Hymenoptera: Formicidae.

Mauda, E. V., Joseph, G. S., Seymour, C. L., Munyai, T. C., \& Foord, S. H. (2018). Changes in landuse alter ant diversity, assemblage composition and dominant functional groups in African savannas. Biodiversity and Conservation, 27(4), 947-965. doi.org/10.1007/s10531-017-1474-x

Netshilaphala, N. M., Milton, S. J., \& Robertson, H. G. (2005). Response of an ant assemblage to mining on the arid Namaqualand coast, South Africa. African Entomology, 13(1), 162-167.

Sanabria, C., Lavelle, P., \& Fonte, S. J. (2014). Ants as indicators of soil-based ecosystem services in agroecosystems of the Colombian Llanos. Applied Soil Ecology, 84, 24-30.

doi.org/10.1016/j.apsoil.2014.07.001

Sid-Ali, S., Djamila, S. A. A., Fatiha, M. A. A., Ouiza, O., \& Said, S. (2021). Diversity of Ants (Hymenoptera, Formicidae) in Two Forest Sites from Kabylia of Djurdjura, Northern Algeria. Sociobiology, 68(3). doi.org/10.13102/sociobiology.v68i3.6232

Suguituru, S. S., Silva, R. R., Souza, D. R. D., Munhae, C. D. B., \& Morini, M. S. D. C. (2011). Ant community richness and composition across a gradient from Eucalyptus plantations to secondary Atlantic Forest. Biota Neotropica, 11, 369-376.

Vasconcelos, H. L., Leite, M. F., VILHENA, J. M., Lima, A. P., \& Magnusson, W. E. (2008). Ant diversity in an Amazonian savanna: relationship with vegetation structure, disturbance by fire, and dominant ants. Austral Ecology, 33(2), 221-231. doi.org/10.1111/j.1442-9993.2007.01811.x

Viglizzo, E. F., Lértora, F., Pordomingo, A. J., Bernardos, J. N., Roberto, Z. E., \& Del Valle, H. (2001). Ecological lessons and applications from one century of low external-input farming in the pampas of Argentina. Agriculture, Ecosystems \& Environment, 83(1-2), 65-81. doi.org/10.1016/S01678809(00)00155-9 
Watt, A. D., Stork, N. E., \& Bolton, B. (2002). The diversity and abundance of ants in relation to forest disturbance and plantation establishment in southern Cameroon. Journal of Applied Ecology, 39: 18-30. doi.org/10.1046/j.1365-2664.2002.00699.x

\section{Figures}



Figure 1 
Map of the study area with samples distribution

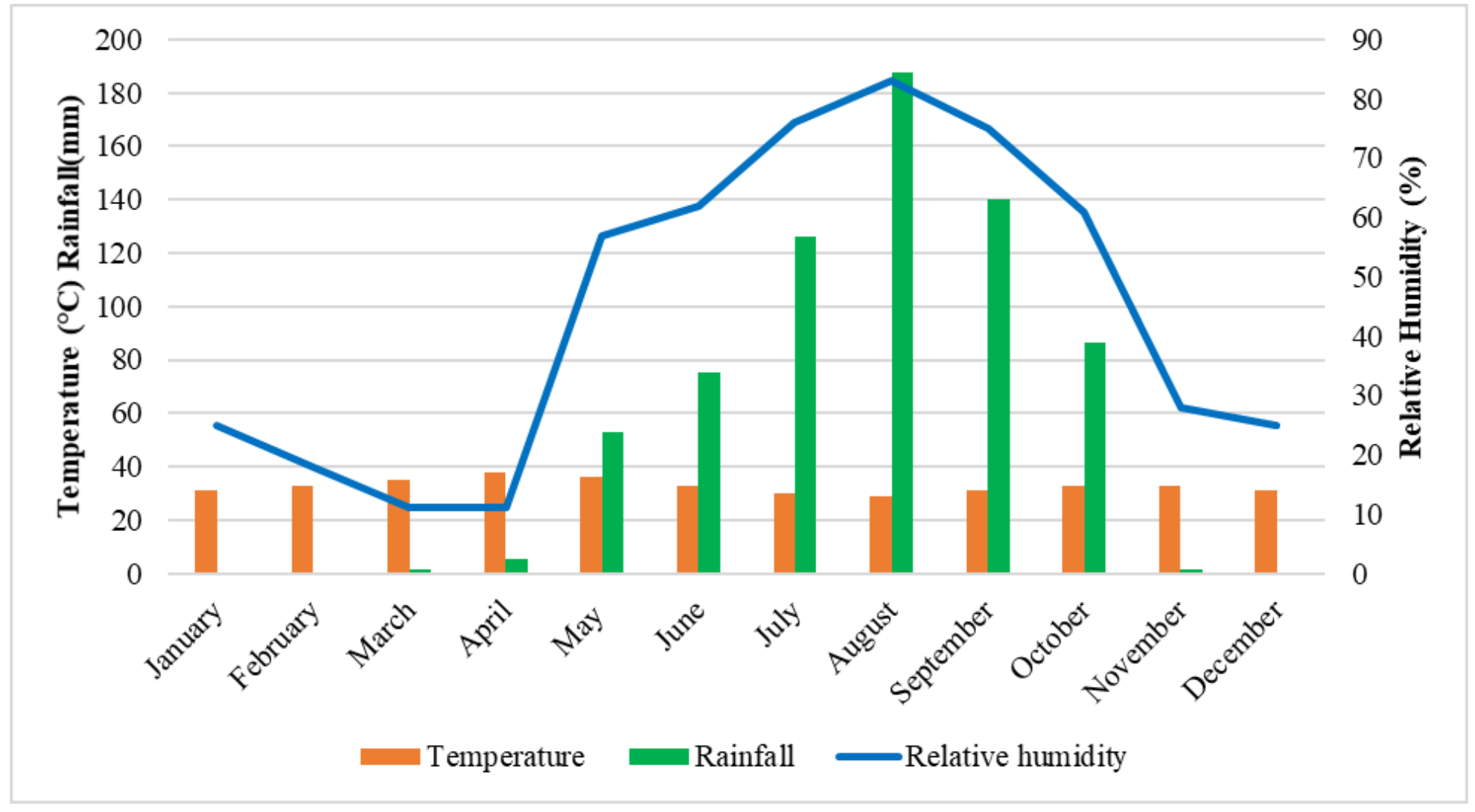

Figure 2

Mean monthly temperature, rainfall and relative humidity of the study area. 


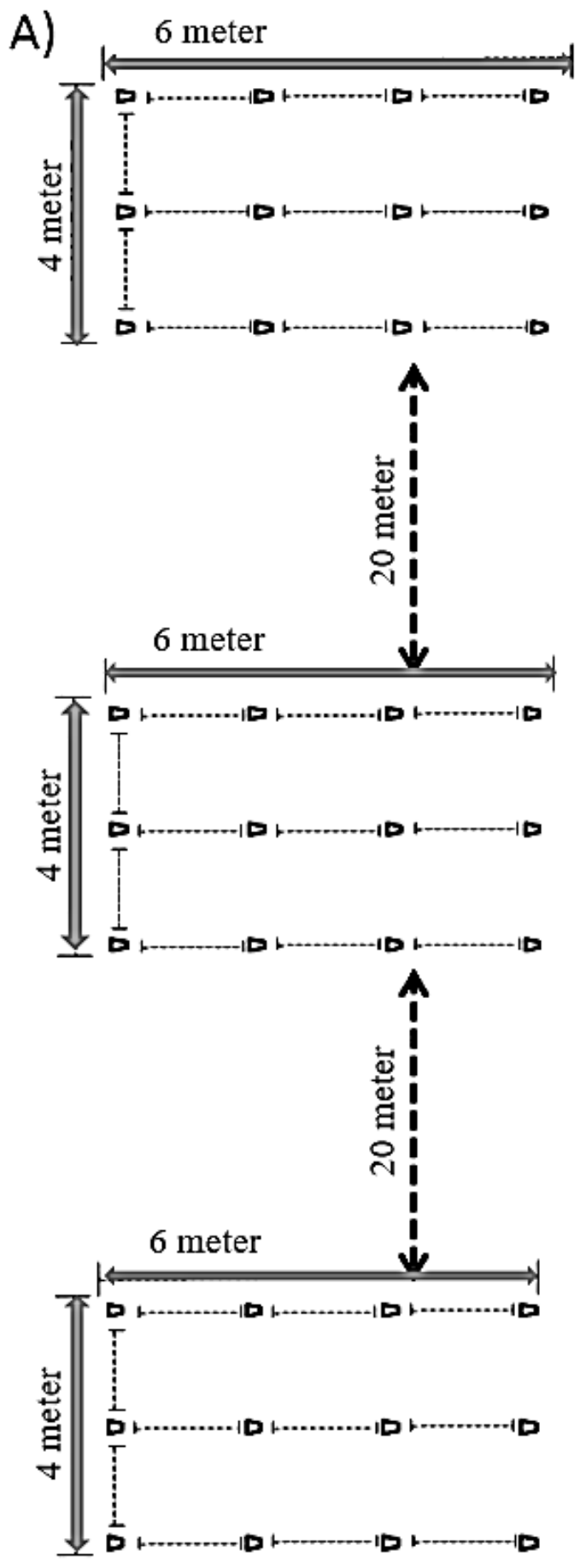

B)
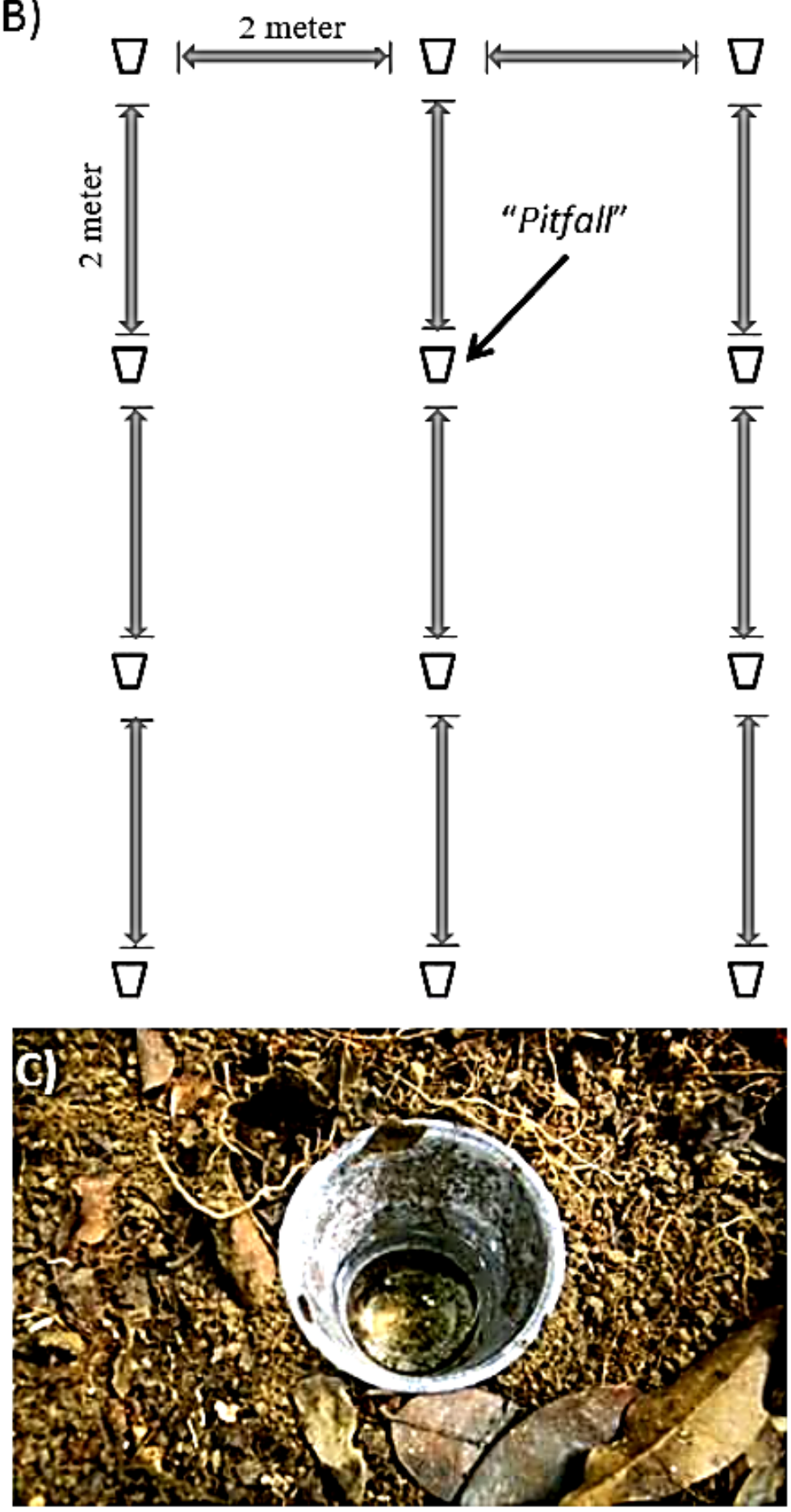

Figure 3

Method used to collect ants. A) Distribution of sample plots in each location. B) Distribution of pitfalls in each sample plot. C) Photograph of a pitfall in the field. 


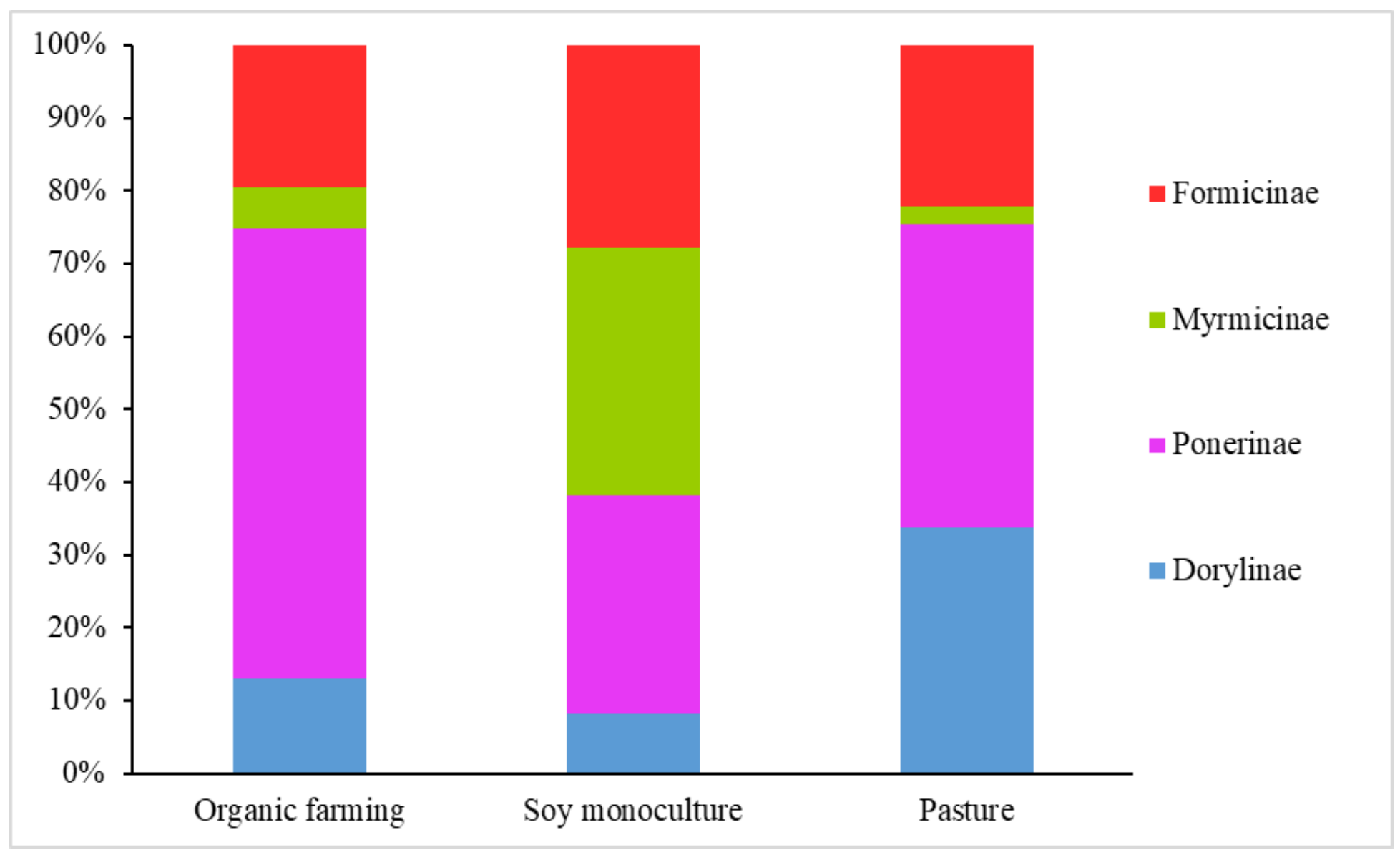

Figure 4

Percentage of morphospecies by subfamily in the three land use in the Rashad district, Southern Kordofan, Sudan. 




Figure 5

Abundance of individuals by species. Top 7 species in each stratum showed, in terms of abundance 


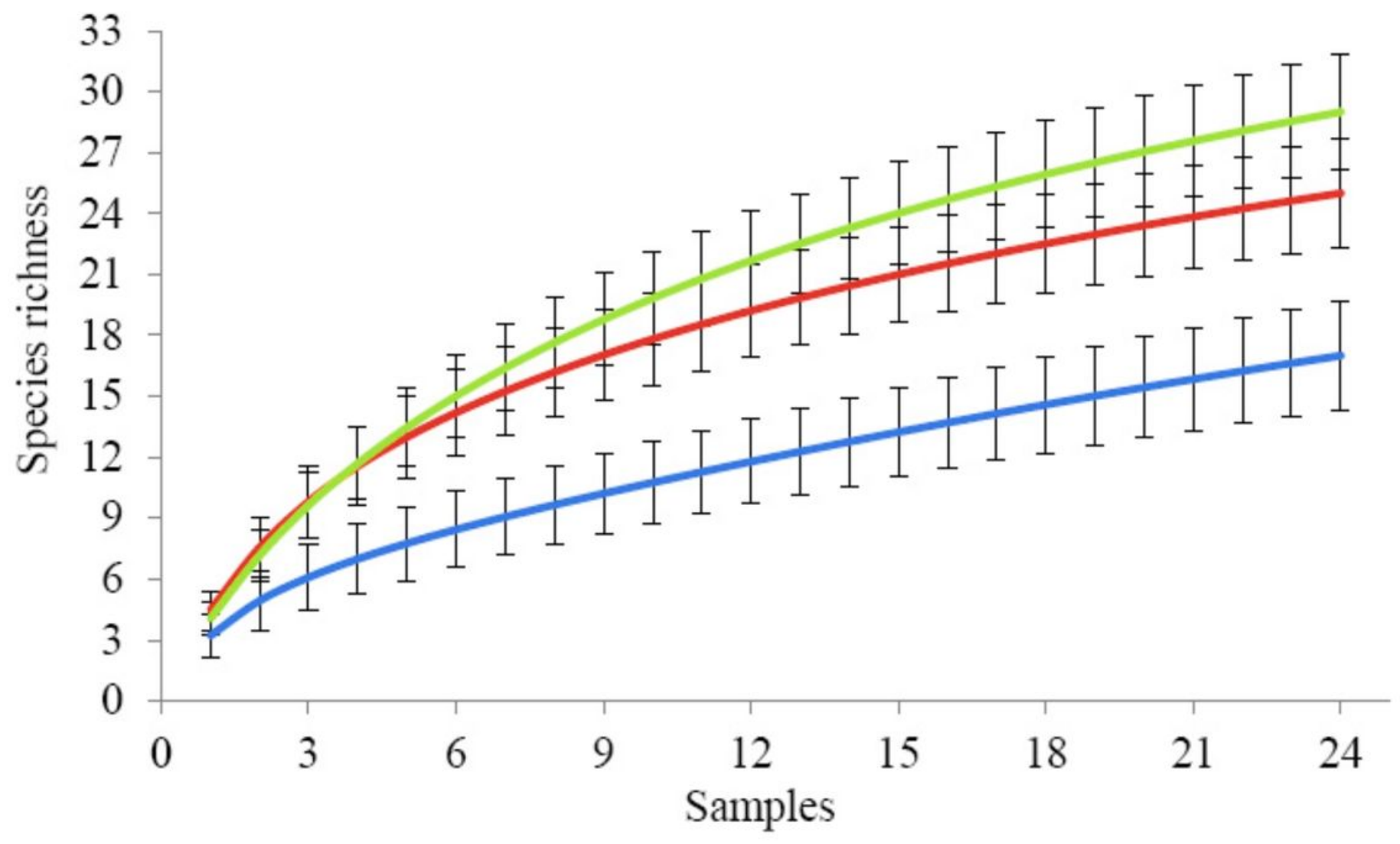

- Pasture - Organic farming - Soy monoculture

Figure 6

Observed species richness for Organic farming, Soy monoculture and Active Pasture. Differences are considered to be statistically significant when $95 \%$ confidence intervals (C.I.) do not overlap $(a=0.05)$. 


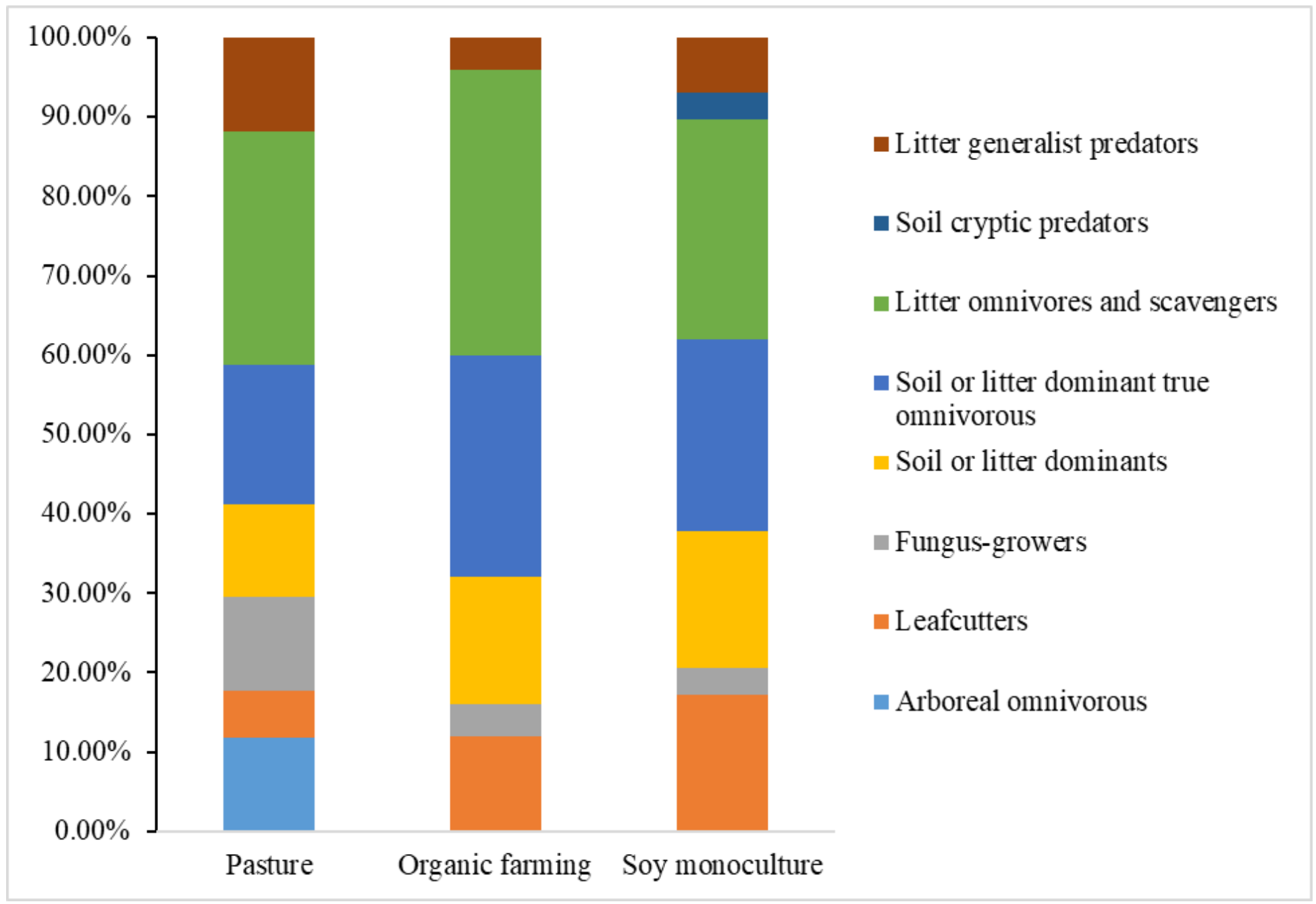

Figure 7

Functional group of each land use in the Rashad district, Southern Kordofan, Sudan. 